same direction. But all this in a sense has little bearing upon the need for the formation of a College of Psychiatrists. We should not ask ourselves what is good for the Royal College of Physicians of London but what is good for psychiatry and its study and practice. It seems a waste of time and effort and money for the medical graduate who intends to become a psychiatrist to have to take two more diplomas in order to embark upon a career in the National Health Service as a psychiatrist-wasteful, we would suggest, for such a man or woman to have to take the M.R.C.P. (Lond. or Edin.) as well as the D.P.M. With the strict selection of medical students, with increasing numbers taking a university qualification in order to register, and with the requirement that one year, and possibly soon two years, should be spent in hospital work before registration, there seems little if any point in requiring a psychiatrist to go back to medical school again in order to take another general medical qualification as well as his D.P.M. In fact such a requirement is a hindrance rather than a help, a discouragement rather than an incentive. If the formation of a College of Psychiatrists would help to bring to an end this current British obsession with examinations, then we would favour the establishing of such a college.

But more important than this is the effect upon psychiatry itself and its development as an art and science of medicine. A College of Psychiatrists would provide a focus of interest and loyalty, a stimulus to research, and encouragement of high clinical and intellectual standards. It is strange indeed that the study of derangement of the mind has no institutional representation comparable with those numerous and even ancient structures concerned with the study of the body.

\section{Pathogenesis of Atherosclerosis}

At p. 517 of this issue Sir George Pickering has presented a stimulating and provocative view of the pathogenesis of atherosclerosis in relation to myocardial and cerebral infarction. His reference to the Augean stables of atherosclerosis is particularly appropriate to the chaotic state of research on this disorder. He points also to the misuse of the term atherosclerosis, in that degeneration of the media of large arteries, retinal arteriosclerosis, and arteriolar sclerosis are frequently confused with atherosclerosis.

Atherosclerosis may be defined as a multifocal, proliferative, and degenerative process affecting mainly the intima of the large elastic arteries and certain muscular arteries. The proliferative element is a sclerotic reaction of the connective tissues of the intima of the artery. The degenerative changes are characterized by accumulation of lipid, hyalinization and fragmentation of connective tissues, calcification, and ischaemic necrosis. By implication Pickering suggests that investigation of changes in the lipids, polysaccharides, and enzymes in the ageing arterial wall has little relevance to the problem of arterial thrombosis. He points out that many research workers may be busily engaged in finding answers to the wrong questions. But a question that bothers many people studying atherosclerosis remains unanswered: What are the right questions ?

Pickering is clearly unimpressed with the theory that atheroma arises from the filtration of lipid into the artery wall, ${ }^{1-4}$ and he apparently does not consider that failure of metabolism in the ageing arterial wall (leading to possible accumulation of $\operatorname{lipid}^{5-9}$ ) has any part in the disorder that leads to thrombosis. He comes out in strong support of encrustation as the major mechanism of the pathogenesis of the disease. The essence of the encrustation theory ${ }^{10-13}$ is that deposits of fibrin and thrombus on the surface of the arterial wall become organized, and the intima becomes sclerosed, scarred, and thickened.

By themselves none of these theories can account for all the features of atherosclerosis in man. Lipid infiltration does not explain the presence of fibrin within the intima ${ }^{1: 4}$; encrustation of thrombus and fibrin does not account for the massive accumulation of lipid in the pultaceous plaque of " atheroma" ; and metabolic failure and changes in permeability in the ageing arterial wall do not explain the susceptibility of the atherosclerotic artery to occlusion by thrombosis. From this sort of evidence many investigators would conclude that atherosclerosis results from the interplay of many factors. On the other hand, Pickering does not appear to favour the multifactorial hypothesis and emphasizes the role of massive encrustation by platelet thrombi. He believes that nodular arteriosclerosis is the only type of degenerative arterial disorder that progresses to fatal occlusion and that its pathogenesis is unique-namely, organization of previous thrombi and thrombotic encrustations. Other forms of atherosclerosis, presumably including the lipid-rich plaque, are regarded as having no part in the development of fatal arterial occlusion. There will be considerable disagreement about these views, particularly by those workers who have examined the varied nature of the constituents in the atherosclerotic area underlying a recent coronary thrombus. Some coronary arteries may show a " geological" structure, ${ }^{15}$ indicating that thrombosis has occurred in the past; others appear to be affected only by the excessively " fatty" type of atherosclerosis.

Pickering's observations on the fate of mural and stenosing thrombi in the heart, aorta, carotid artery, and subclavian artery are convincing evidence that encrustation does cause a type of atherosclerosis. However, lipid accumulation does not appear to be a major feature of the lesions that he describes. Similarly scanty amounts of lipid are present in

Anitschow, N., and Chalatow, S., Zbl. allg. Path. path. Anat., 1913, 24, 1.

2 Leary, T., Arch. Path., 1941, 32, 507.

Wissler, R. W., Eilert, M. L., Schroeder, M. A., and Cohen, L., ibid., 1954, 57, 333 .

Marmorston, J., Rosenfeld, S., and Mehl, J., in Hormones and Atherosclerosis, 1959, edited by G. Pincus, p. 213 . Academic Press, New York.

Page, I. H., Circulation, 1954, 10, 1.

Wilens, S. L., Science, 1951, 114, 389.

Duncan, L. Ë., jun., and Buck, K., Circulat. Res., 1960, 8, 1023.

Adams, C. W. M., Bayliss, O. B., and Ibrahim, M. Z., Lancet, 1962,

1, 890 .
Courtice, F. C., and Garlick, D. G., Quart. 7. exp. Physiol., 1962, 47, 221 .

10 Duguid, J. B., Lancet, 1952, 2, 207.

${ }_{11}$ Crawford, T., and Levene, C. I., 7. Path. Bact., 1952, 64, 523.

12 Morgan, A. D., The Pathogenesis of Coronary Occlusion, 1956. Blackwell, Oxford.

Rannie, I., in C.R. IVe Congrès International d'Angeiologie, 1962, p. 552. 'Prague.

Woolf, N., and Crawford, T., F. Path. Bact., 1960, 80, 405.

Osborn, G. R., The Incubation Period of Coronary Thrombosis, 1963. Butterworths, London.

Harrison, C. V., F. Path. Bact., 1948, 60, 289.

Heard, B. E., ibid., 1952, 64, 13.

Hand, R. A., and Chandler, A. B., Amer. F. Path., 1962, 40, 469.

19 Gore, I., Tanaka, K., and Larkey, B. J., ibid., 1963, 42, 345.

20 Fore, I., Tanaka, K., and Larkey, B. J., ibid., 1963, 42, 345. 1962, 1, 501.

Schwartz, C. J., and Mitchell, J. R. A., Circulat. Res., 1962, 11, 63.

Strong, J. P., Wainwright, J., and McGill, H. C., Circulation, 1959, 20, 118

${ }_{23}$ Anitschow, N., in Arteriosclerosis, 1933, edited by E. V. Cowdry, p. 271. Macmillan, New York.

Constantinides, P., f. Atheroscler. Res., 1961, 1, 374.

Gresham, G. A., and Howard, A. N., Arch. Path., 1962, 74, 1.

Taylor, C. B., Cox, G. E., Manalo-Estrella, P., and Southworth, J., ibid., 1962, 74, 16.

Adams, C. W. M., Bayliss, O. B., Ibrahim, M. Z. M., and Webster, M. W., jun., f. Path. Bact., 1963, 86, 431. 
the organized emboli produced experimentally in the pulmonary arteries of animals. ${ }^{16-19}$ The lesions that result from encrustation differ, therefore, from both "atheroma" in human arteries, which is rich in lipid, and spontaneous atherosclerosis in animals, in which encrustation does not occur. ${ }^{20}$

The relatively non-sclerotic "fatty streak" in the human aorta has a different anatomical site and histological appearance $^{21}$ from fibrous and fatty atherosclerotic plaques. Likewise, these fatty streaks are common in the South African Bantu, ${ }^{22}$ who develop only minor degrees of atherosclerosis. But the early fatty and non-sclerotic lesions, produced by feeding animals with a diet rich in cholesterol or triglyceride, develop eventually into fibro-fatty plaques resembling those seen in human atherosclerosis. ${ }^{23-26}$ Cholesterol is in fact potent in producing sclerosis, ${ }^{27}$ and will excite an inflammatory response just as severe as that which occurs when encrustations on the intima become organized. From these observations it can only be concluded that the lesions of atherosclerosis are as diverse as the pathogenic mechanisms that lead to their formation, and it may therefore be premature to regard any one of these atherogenic mechanisms as the sole factor that leads on to arterial occlusion.

\section{Colds and Their Viruses}

We can no longer talk about the "common cold virus," because many viruses which can cause colds are now known. ${ }^{12}$ But to know that a virus exists and that it can cause a cold or other upper respiratory infection is only the beginning. Fortunately, many different groups of workers are now studying the problem, and from their results we are learning what varieties of disease some of the "new" respiratory viruses cause and also something of their prevalence and epidemiology.

For example, the parainfluenza virus type 2 was discovered in cases of severe infection of the lower respiratory tractnamely, croup or acute laryngotracheobronchitis of small children, a disease with which it seems to be causally

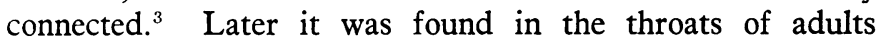
suffering from relatively mild disease. ${ }^{4}$ Then at the Common Cold Research Unit, Salisbury, the third clause of Koch's postulates was fulfilled by cultivating the virus in vitro and causing disease on giving it back to man. A mild cold-like disease with relatively little coryza was produced in eight out of twenty-eight volunteers. ${ }^{5}$ Also during last year a careful study of a small epidemic of parainfluenza virus type 2 infection has been reported. ${ }^{6}$ The outbreak occurred in a children's home, and two results were of special importance. One was that a correlation was found between the presence of the virus in the throat and the occurrence of a febrile illness -two-thirds of 15 infected children were ill. The other was that the illness observed was "croup" in only one case ; in the remaining nine it was upper respiratory illness or fever only, and there were two cases of otitis media.

This was an isolated epidemic and the conditions were quite unlike general practice, but Drs. J. E. Banatvala, T. B. Anderson, and B. B. Reiss in this issue of the B.M.F. describe (page 537) the importance of parainfluenza viruses in the "run-of-the-mill" respiratory infections seen so frequently by the general practitioner. They attempted both to isolate parainfluenza viruses and to detect infection by serological tests. However, they studied only febrile cases, and many patients in their practice may have had milder diseases which they never reported to the doctor. They found parainfluenza type 1 was the commonest virus and type 3 was less so, but 2 of 21 parainfluenza viruses isolated from children belonged to type 2. By serological tests they also recognized fourteen cases of infection with parainfluenza viruses in adults. There appeared to be an epidemic wave of infections with the type 1 virus. The illness often seemed to spread to other members of the family, children rather than adults being affected, and on a few occasions infection with the same virus in both patients was diagnosed by laboratory tests. The illness was marked by cough and a hoarse voice; barely half of the children had a running nose or sore throat.

Various other viruses related to the enteroviruses have been isolated from patients with colds. They have been named ECHO 28 virus, Salisbury strains, entero-like or enteroviruses, coryzaviruses, and muriviruses. It is now known that all these viruses may be distinguished from enteroviruses in the laboratory because they are unstable in acid solution $(p \mathrm{H} 3 \text { to } 5)^{78}$ and it has been agreed to call them all rhinoviruses, ${ }^{9}$ and to combine them with enteroviruses into the larger group of the picorna viruses-that is, small (pico) viruses containing R.N.A. as their nucleic acid. The rhinoviruses are called $M$ strains if they affect monkey cells as well as human cells in vitro and $\mathrm{H}$ if they attack human cells only.

There are numerous serotypes of rhinoviruses, but they all seem to cause colds when given to human volunteers, a disease which is generally afebrile and milder than that described by Dr. Banatvala and his colleagues. Several groups of workers are now studying the distribution of these viruses in various populations. D. Hamre and J. J. Procknow, ${ }^{10}$ found six parainfluenza viruses and nearly a hundred rhinoviruses in 406 cases of common colds in medical students. They showed that certain individuals who had repeated colds had repeated infections with rhinoviruses as well as infections with parainfluenza viruses. They rarely recovered viruses from subjects without colds. An investigation at an American military base also showed an association in adults between colds and infection with rhinoviruses, while a wave of $M$ rhinovirus infections was found to be distinct from a wave of $\mathrm{H}$ rhinovirus infections. Rhinoviruses were recovered from children less frequently than from adults. ${ }^{11}$ The illnesses in adults were typical mild colds which could not be distinguished clinically from colds due to Coxsackie A21 virus (Coe virus), though a group of illnesses produced

1 Stuart-Harris, C. H., Brit. med. F., 1962, 1, 1779, and 2, 869.

2 See Brit. med. F., 1962, 2, 905.

3 Kim, H. W., Vargosko, A. J., Chanock, R. M., and Parrott, R. H., Pediatrics, 1961, 28, 614.

Mogabgab, W. J., Dick, E. C., and Holmes, B., Amer. f. Hyg., 1961, 74, 304 .

Taylor-Robinson, D., and Bynoe, M. L., f. Hyg. (Lond.), 1963, 61, 407.

6 Kapikian, A. Z., Bell, J. A., Mastrota, F. M., Huebner, R. J., Wong, D. C., and Chanock, R. M., f. Amer. med. Ass., 1963, 183, 324.

Dimmock, N. J., and Tyrrell, D. A. J., Lancet, 1962, 2, 536.

Ketler, A., Hamparian, V. V., and Hilleman, M. R., Proc. Soc. exp. Biol. (N.Y.), 1962, 110, 82i.

9 Tyrrell, D. A. J., and Chanock, R. M., Science, 1963, 141, 152.

10 Hamre, D., and Procknow, J. J., Amer. Rev. resp. Dis., 1963, 88, 277.

11 Bloom, H. H., Johnson, K. M., Forsyth, B. R., and Chanock, R. M., f. Amer. med. Ass., 1963, 186, 38.

12 Forsyth, B. R., Bloom, H. H., Johnson, K. M., and Chanock, R. M., New Engl. f. Med., 1963, 269, 602.

13 Pereira, M. S., Hambling, M. H., McDonald, J. C., and Zuckerman, A. J., f. Hyg. (Lond.), 1963, 61, 471.

14 Taylor-Robinson, D., Johnson, K. M., Bloom, H. H., Parrott, R. H., Mufson, M. A., and Chanock, R. M., Amer. F. Hyg., 1963, 78, 285. 5 Mufson, M. A., et al., f. Amer. med. Ass., 1963, 186, 578.

${ }_{15}$ Mufson, M. A., et al., f. Amer.

${ }_{17}$ Carilli, A. D., Gohd, R. S., and Gordon, W., New Engl. F. Med., 1964, 270, 123.

18 Sommerville, R. G., Lancet, 1963, 2, 1247.

19 Sandiford, B. R., and Spencer, B., Brit. med. F., 1962, 2, 881.

20 Andrew, J. D., and Gardner, P. S., ibid., 1963, 2, 1447. 